\title{
PENGEMBANGAN SISTEM INFORMASI PEMESANAN BARANG ONLINE BERBASIS ANDROID DI ORION IT SOLUTION
}

\author{
Dzikri Nadhimulloh ${ }^{1}$

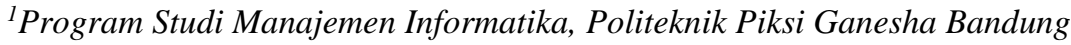 \\ Email: ${ }^{1}$ nadhimulloh@gmail.com
}

\begin{abstract}
ABSTRAK
Saat ini Orion IT Solution bergerak dalam perancangan dan pembuatan aplikasi multiplatform. Seiring dengan kesuksesan dalam bidang tersebut maka pimpinan Orion IT Solution akan menyiapkan tambahan divisi dalam bidang hardware. Dalam bidang tersebut Orion IT Solution akan bergerak sebagai supplier hardware dan aksesoris komputer untuk daerah jawa barat khususnya bandung dan sekitarnya. Sistem informasi untuk mengelola divisi baru tersebut telah dibuat oleh pimpinan tetapi masih dalam bentuk aplikasi desktop dan hanya mengatur proses bisnis untuk internal saja. Metode yang penulis gunakan ialah metode RAD. Penulis telah menganalisa sistem yang sudah ada dan akan mengembangkan sistem informasi tersebut dengan menambahkan fitur pemesanan barang secara online yang dapat dilakukan oleh customer secara realtime. Terdapat fitur pemesanan, histori transaksi, keranjang dan lainnya. Fitur tersebut akan memberikan dampak positif yang besar dalam membantu kelancaran dan kecepatan pada proses bisnis ini.
\end{abstract}

Kata Kunci: Pengembangan, Aplikasi, Android, RAD.

\section{PENDAHULUAN}

\subsection{Latar Belakang}

Teknologi informasi dan komunikasi semakin berkembang pesat saat ini. Teknologi internet mempunyai pengaruh yang cukup besar dalam segala bidang khususnya dalam hal pemesanan barang bagi suatu perusahaan. Pemesanan barang yang dilakukan melalui internet ini bisa disebut juda dengan e-Commerce (Electronic Commerce). Terdapat kemudahan dari sisi customer seperti hanya dengan dari rumah atau dimana pun berada, melakukan pemesanan yang dibutuhkan toko mereka ataupun dapat melihat produk-produk yang tersedia, mengakses informasi dan memesan barang secara online.

Orion IT Solution adalah perusahaan yang telah lama bergerak dibidang IT, khususnya dalam pembuatan aplikasi atau software yang telah berdiri sejak tahun 2003. Sejauh ini Orion IT Solution sudah terbiasa dalam menangani perancangan dan pembuatan aplikasi yang berbasis desktop, android ataupun website.

Seiring dengan keinginan berkembangnya perusahaan tersebut, pimpinan Orion IT akan mengembangkan cakupannya kedalam bidang hardware, Orion IT akan bergerak menjadi supplier hardware dan aksesoris komputer untuk kawasan jawa barat khususnya bandung dan sekitarnya.

Aplikasi sistem pengelolaan bisnisnya sudah dikembangkan oleh tim internal diperusahaan tersebut. Sistem yang ada sudah mencakup dari master data, transaksi barang, dan laporan-laporan. Sistem tersebut masih dalam tahap pengembangan dan hanya mengelola pada sisi internal saja.

Setelah penulis melakukan analisis pada sistem yang sudah ada, penulis memiliki kesimpulan untuk mengembangkan aplikasi tersebut dengan menambah fitur pemesanan barang secara online dan dapat langsung dilakukan oleh customer pada smartphone masing-masing. Fitur tersebut akan sangat membantu untuk kedua belah pihak, proses pemesanan barang akan lebih cepat dilakukan.

Tidak terbatas hanya untuk pemesanan barang, aplikasi hasil pengembangan penulis pun akan menyediakan beberapa fitur seperti keranjang, wishlist, informasi tentang barang, histori pemesanan, dan lainnya. Dengan begitu customer akan mendapatkan data yang selalu terupdate tentang barang yang disediakan oleh Orion IT Solution ini.

Alasan penulis memakai platform android tidak lain karena banyak sekali dukungan dari berbagai vendor serta kemudahan yang dimilikinya (Muhammad Robith Adani, 2020). Aplikasi dapat diakses dimanapun, karena system ini dibangun pada platform Android yang memiliki market share sebesar 71,93\% secara global (O’Dea, 2021). Untuk data yang diperoleh dari aplikasi desktop penulis menggunakan API karena lebih memudahkan dalam mengaksesnya (Muhammad Robith Adani, 2020). Database yang digunakan adalah MySql tidak lain karena mendukung penggunaan multi user (Muhammad Robith Adani, 2020) dan banyak lagi kelebihan lainnya.

\subsection{Tinjuan Pustaka}

Berikut merupakan tinjauan kembali dari pustaka yang penulis peroleh dan penulis jadikan dasar penelitian saat ini, yaitu:

1. E-Commerce merupakan salah satu teknologi yang berkembang pesat pembelian dan penjualan barang dan jasa melalui jaringan electronik seperti internet. E-commerce merupakan suatu cara berbelanja secara online yang memang seiring dengan kehadiran 
internet dalam kehidupan kita (Kasmi, Adi Nurdian Candra, 2017: 109-116).

2. Perancangan atau rancang merupakan serangkaian prosedur untuk menterjemahkan hasil analisa dan sebuah sistem ke dalam bahasa pemrograman untuk mendeskripsikan dengan detail bagaimana komponen-komponen sistem di implementasikan (Pressman, 2009).

3. Sistem adalah Sekelompok elemen-elemen yang terintegrasi dengan tujuan yang sama untuk mencapai tujuan (Tashia, 2017).

4. Android studio adalah IDE (Integrated Development Environment) resmi untuk pengembangan aplikasi Android dan bersifat open source atau gratis. Peluncuran Android Studio ini diumumkan oleh Google pada 16 mei 2013 pada event Google I/O Conference untuk tahun 2013. Sejak saat itu, Android Studio mengantikan Eclipse sebagai IDE resmi untuk mengembangkan aplikasi Android (Andi Juansyah, 2015).

\subsection{Metodologi Penelitian}

Tahap penelitian dimulai dari pendahuluan yang meliputi latar belakang, identifikasi masalah, rumusan masalah, batasan masalah serta tujuan dan manfaat penelitian. Tahap ini juga merupakan tahap awal dalam metodologi pengembangan sistem model Rapid Apllication Development (RAD) sebagai tahap untuk mendefinisikan persyaratan persyaratan.

Perancangan aplikasi ini dilakukan menggunakan metode Rapid Application Development karena metode ini mempunyai keunggulan dibanding metode konvensional lainya (Noertjahyana, 2002), seperti kecepatan, ketepatan serta biaya yang relatif lebih murah. Metode ini digunakan juga mempertimbangkan aplikasi ini akan memiliki update fitur sesuai dengan kebutuhan kedepanya menjadi akan lebih mudah.

Tahap berikutnya yaitu pengumpulan data, dalam pengumpulan data ada tiga teknik yang di gunakan yaitu observasi, wawancara dan studi literatur. Kemudian di lanjutkan dengan tahap desain workshop dan implementasi. Sampai dengan tahap terakhir yaitu penutup yang bersisi kesimpulan dan saran.

Metodologi pengembangan perangkat lunak yang digunakan adalah Metode Rapid Application Development (RAD). Menurut Kendall (2010), RAD adalah suatu pendekatan berorientasi objek terhadap pengembangan sistem yang mencakup suatu metode pengembangan serta perangkat perangkat lunak. RAD bertujuan mempersingkat waktu yang biasanya diperlukan dalam siklus hidup pengembangan sistem tradisional antaraperancangan dan penerapan suatu sistem informasi. Pada akhirnya, RAD sama-sama berusaha memenuhi syarat-syarat bisnis yang berubah secaracepat.

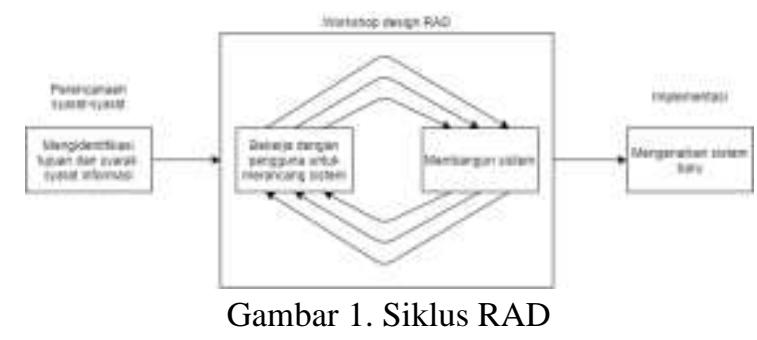

Berikut ini adalah tahap-tahap pengembangan aplikasi dari tiap-tiap fase pengembangan aplikasi (Kendall, 2010).

a. Requirements Planning (Perencanaan SyaratSyarat)

Dalam fase ini, pengguna dan penganalisis bertemu untuk mengidentifikasikan tujuan Registrasi Login tujuan aplikasi atau sistem serta untuk megidentifikasikan syarat-syarat informasi yang ditimbulkan dari tujuan-tujuan tersebut.

Orientasi dalam fase ini adalah menyelesaikan masalah-masalah perusahaan. Meskipun teknologi informasi dan sistem bisa mengarahkan sebagian dari sistem yang diajukan, fokusnya akan selalu tetap pada upaya pencapaian tujuan-tujuan perusahaan.

b. RAD Design Workshop (Workshop Desain RAD)

Fase ini adalah fase untuk merancang dan memperbaiki yang bisa digambarkan sebagai workshop. Penganalisis dan dan pemrogram dapat bekerja membangun dan menunjukkan representasi visual desain dan pola kerja

kepada pengguna. Workshop desain ini dapat dilakukan selama beberapa hari tergantung dari ukuran aplikasi yang akan dikembangkan.

Selama workshop desain RAD, pengguna merespon prototipe yang ada dan penganalisis memperbaiki modul-modul yang dirancang berdasarkan respon pengguna. Apabila sorang pengembangnya merupakan pengembang atau pengguna yang berpengalaman, Kendall menilai bahwa usaha kreatif ini dapat mendorong pengembangan sampai pada tingkat terakselerasi.

c. Implementation (Implementasi).

Pada fase implementasi ini, penganalisis bekerja dengan para pengguna secara intens selama workshop dan merancang aspek-aspek bisnis dan nonteknis perusahaan. Segera setelah aspek-aspek ini disetujui dan sistem sistem dibangun dan disaring, sistem-sistem baru atau bagian dari sistem diujicoba dan kemudian diperkenalkan kepada organisasi.

2. PEMBAHASAN

2.1. Use Case Diagram

Use case diagram dapat dilihat pada gambar 2 


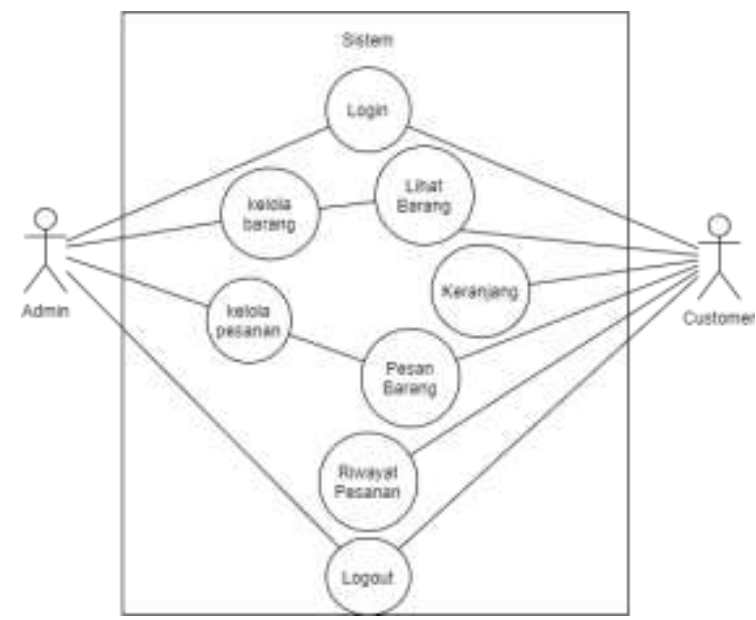

Gambar 2. Use Case diagram

Pada usecase diagram tersebut, ada 2 aktor didalamnya yaitu admin dan customer, pada aplikasi yang penulis kembangkan, customer dapat melakukan beberapa aksi diawali dengan login lalu dapat mengakses lihat barang, keranjang, pesan barang dan riwayat pesanan. Untuk admin mengelola data barang dan pesanan berada dalam cakupan aplikasi desktop dalam aplikasi yang sudah ada sebelumnya.

\subsection{Class Diagram}

Dalam class diagram ini menjelaskan tentang struktur sistem dari segi pendefinisian kelas - kelas yang akan dibuat untuk membangun sistem tersebut.

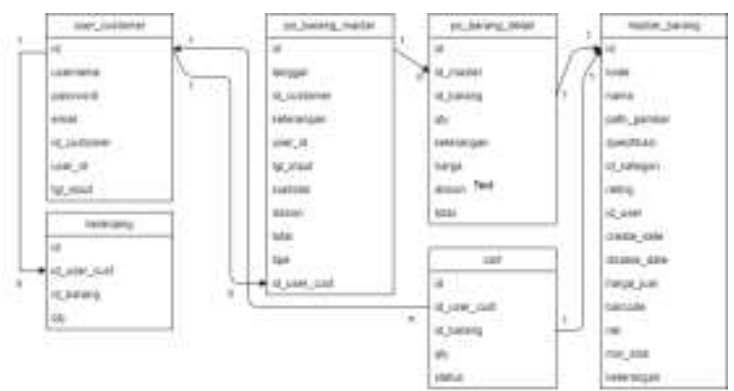

Gambar 3. Class diagram

Class diagram menggambarkan design table yang dibuat untuk aplikasi yang penulis rancang. Disini terlihat relasi-relasi antar class yang telah penulis buat.

\subsection{Tampilan Aplikasi}

Berikut merupakan tampilan aplikasi yang penulis telah dibuat:

1. Login

Berikut adalah tampilan dari form login, customer (user) diharuskan mengisi username dan password yang sudah didaftarkan sebelumnya oleh admin untuk mengakses keseluruhan fitur pada aplikasi ini.

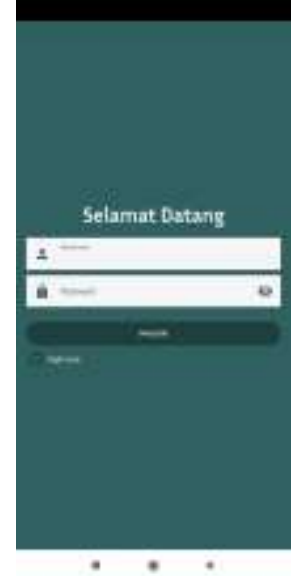

2. Beranda

Gambar 4. Login Form

Dibawah ini merupakan tampilan beranda, ada fitur search pada bagian atas dan beberapa menu yang dapat user akses langsung.

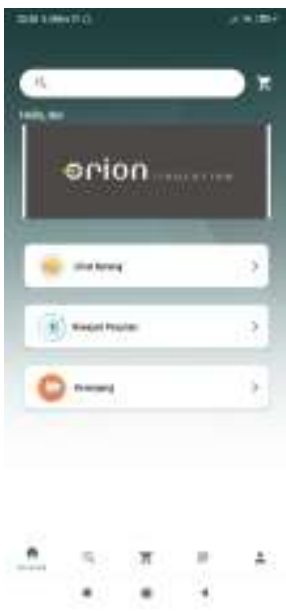

Gambar 5. Beranda

3. Cari Barang

User dapat mencari suatu barang yang diinginkan dengan menggunakan fitur ini, terdapat filter berupa kategori dan lainnya.
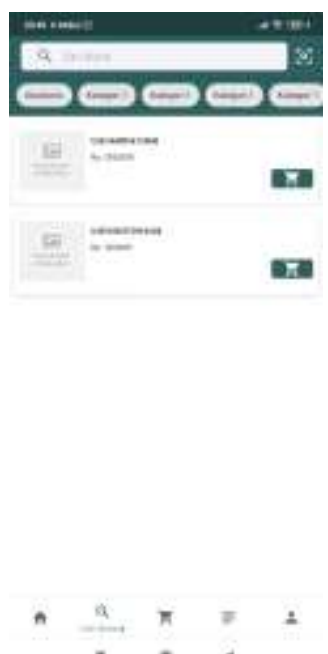

Gambar 6. Cari Barang 


\section{Keranjang}

Setelah user melihat barang dan memasukan ke keranjang, berikut tampilan keranjangnya, user dapat merubah qty menghapus dari cart dan atau memprosesnya (checkout).
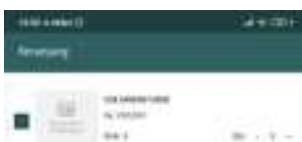

\section{Checkout}

Merupakan proses terakhir sebelum pemesanan, user dapat melihat barang apa saja yang akan di pesan. Setelah tombol Order diklik, pesanannya akan di teruskan ke bagian admin di kantor untuk di proses.
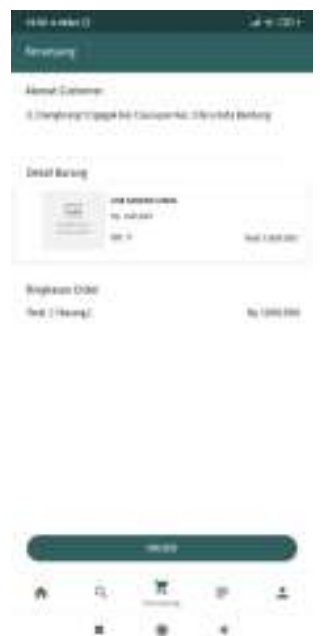

Gambar 7. Checkout

6. Profil

User atau customer dapat melihat profilnya pada menu ini, pada submenu detail profil, disitu terdapat data customer, detail alamat dan lain sebagainya.

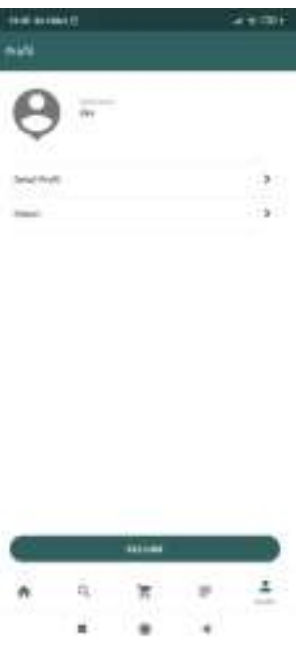

Gambar 8. Profil

7. Riwayat

Seluruh transaksi pemesanan yang dilakukan akan terlihat disini, baik yang berhasil maupun yang tidak berhasil.
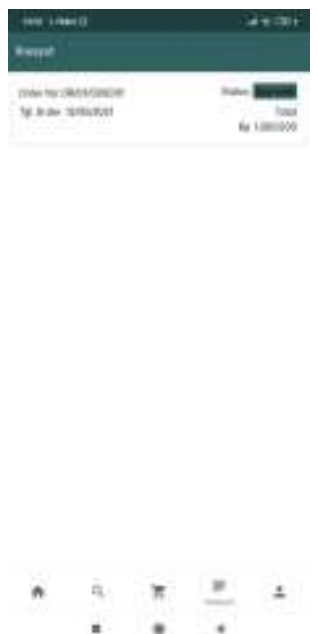

Gambar 9. Riwayat

\section{KESIMPULAN}

Dari uraian yang terdapat pada laporan ini, maka penulis menarik beberapa kesimpulan sebagai berikut :

1. Sistem order online yang penulis buat sangat memiliki manfaat positif untuk keberlangsungan aktivitas pengorderan barang di Orion IT Solution.

2. Sistem yang telah penulis buat dapat menyediakan informasi yang ter-up todate terkait dengan barang yang dipasarkan.

3. Memberikan kemudahan dan percepatan terhadap proses order barang.

\section{PUSTAKA}

Muhammad Robith Adani, 2020, 20 Bahasa Pemrograman Mobile yang Banyak 
Digunakan (https://www.sekawanmedia.c o.id/bahasa-pemrograman-mobile/, diakses 7 Agustus 2021).

S. O'Dea, 2021, (https://www.statista.com/ statistics/272698/global-market-share-held -by-mobile-operating-systems-since-2009/, diakses 7 Agustus 2021).

Muhammad Robith Adani, 2020, Mengenal penggunaan API dan contohnya, (https://www.sekawanmedia.co.id/pengerti an-api/, diakses 7 Agustus 2021).

Muhammad Robith Adani, 2020, Apa itu MySQL: Pengertian, Fungsi, beserta Kelebihan, (https://www.sekawanmedia.co.id/pengerti an-mysql/, diakses 7 Agustus 2021).

Kasmi, Adi Nurdian Candra, 2017, Penerapan eCommerce Berbasis Business To Consumers Untuk Meningkatan Penjualan Produk Makanan Ringan Khas Pringsewu, Jurnal Aktual STIE Trisna Negara, Volume 15 (2), Hal. 109-116.

Pressman, R., \& Maxim, B., 2009, Software Engineering: A Practitioner's Approach (8th ed.). New York: McGrawHill Higher Education.

Tashia. 2017, "Sistem e-Commerce dan Perlindungan Konsumen, (https://aptika.kominfo.go.id/, diakses 7 Agustus 2021).

Andi Juansyah, 2015, "Pembangunan Aplikasi Child Tracker Berbasis Assisted Global Positioning System (A-Gps) Dengan Platform Android", Jurnal Ilmiah Komputer dan Informatika (KOMPUTA), Edisi. 1 Volume. 1.

Noertjahyana, A. 2002, "Studi Analisis Rapid Aplication Development Sebagai Salah Satu Alternatif Metode Pengembangan Perangkat Lunak, (https://jurnalinformatika.petra.ac.id, diakses 7 Agustus 2021)

Kendall, 2010. Tiga Fase dalam Metode Rapid Application Development (RAD). 